\title{
The formation and draining of late Wisconsinan superglacial lakes on the Riding Mountain Uplands, Manitoba
}

\author{
R.A. McGinn \\ Department of Geography, Brandon University, Brandon, Manitoba R7A 6A9, Canada
}

Date Received July 31, 1991

Date Accepted October 18, 1991

\begin{abstract}
The late Wisconsinan deglaciation of the Riding Mountain Uplands was associated with the Lockhart Phase of glacial Lake Agassiz (11,600-10,800 B.P.). During the waning stages of the Falconer ice advance (post 11,400 B.P.) a large area of glacial ice stagnated on the Riding Mountain Uplands. Subsequent downwasting generated a drainage network consisting of several superglacial lakes, spillways and meltwater channels. Many of these glacial rivers eroded their ice beds and incised into the substratum. Glaciofluvial sediments were deposited as sandurs, eskers and kames. Subaqueous fans were deposited in the superglacial lakes and a major delta was built into the north end of glacial Lake Hind. During this time an advance of the Valley River Sublobe created the Mears kame moraine.

Following this advance, Northeastern ice (the Assiniboine Sublobe) retreated from the Rivers - Rapid City Endmoraine to the Brookdale position. As downwasting of the stagnant ice on the uplands continued, the superglacial lakes drained and an entrenched drainage system developed on the stagnant ice moraine complex.
\end{abstract}

La déglaciation du Wisconsinien tardif du plateau de Riding Mountain était associée à la phase Lockhart du lac glaciaire Agassiz (11,600-10,800 B.P.). A la fin de l'avancée glaciaire Falconer (après 11,400 B.P.), une vaste étendue de glace est restée stagnante sur le plateau de Riding Mountain. L'ablation subséquente a laissé un réseau de drainage composé de plusieurs lacs supraglaciaires ainsi que des canaux de débordement et de fonte. Plusieurs de ces rivières glaciaires ont érodé leur lit de glace et le substrat. Les sédiments fluvio-glaciaires ont été déposés sous forme de sandurs, d'eskers et de kames. Des cônes subaqueux ont été déposés dans les lacs supraglaciaires et un delta important a été formé à l'extrémité nord du lac glaciaire Hind. Pendant ce temps, une avancée du lobe secondaire de la rivière Valley a créé la moraine à kames Mears.

Après cette avancée, la partie nord-est du glacier (le lobe secondaire Assiniboine) a reculé, depuis la moraine frontale de Rivers - Rapid City jusqu'à la position de Brookdale. Pendant l'ablation du glacier stagnant sur le plateau, les lacs supraglaciaires se sont drainés et un réseau de drainage encaissé s'est développé sur le complexe de moraine associé au glacier stagnant.

[Traduit par le journal]

\section{INTRODUCTION}

The Riding Mountain Uplands (Fig. 1) cover an area of approximately $6300 \mathrm{~km}^{-2}$ in southwestern Manitoba. They represent one of four prominent shale bedrock uplands that form the $800 \mathrm{~km}$ long Manitoba Escarpment. The Riding Mountain segment of this escarpment rises an average of 370 $\mathrm{m}$ above the Manitoba Plain to a maximum elevation of 732 $\mathrm{m}$ a.s.l. The plateau slopes gently towards the south and southwest merging with the Assiniboine River Plain at an average elevation of $623 \mathrm{~m}$.

The Riding Mountain Uplands are naturally subdivided into three highland plateaux (Fig. 1). The Eastern Uplands represent the largest highland area comprising the Riding Mountain Uplands. The dip slope of the Manitoba Escarpment delineates the eastern edge of this highland plateau and the deeply entrenched Little Saskatchewan River bounds the subregion on the west and the south (Fig. 1). The centrally located Western Uplands are bounded by the entrenched Birdtail River to the northwest and the Little Saskatchewan River on the east. The Northern Highland Plateau is located northwest of the Western Uplands and bounded on the southeast by the Birdtail River.

In the early 1960's R.W. Klassen mapped the Northern, Western and the western half of the Eastern Uplands (Klassen, 1966) and proposed a Wisconsinan deglaciation scenario for the region. Unfortunately, much of Klassen's early deglaciation sequence depended on events which were occurring over the unmapped portion of the Eastern Uplands. Consequently, the proposed deglaciation sequence remained in the original doctoral thesis and was not published elsewhere. Mihychuk and Groom (1979) and Groom (1980) published a preliminary mapping of the surficial deposits of the southeastern segment of the Eastern Uplands. More recently, the 


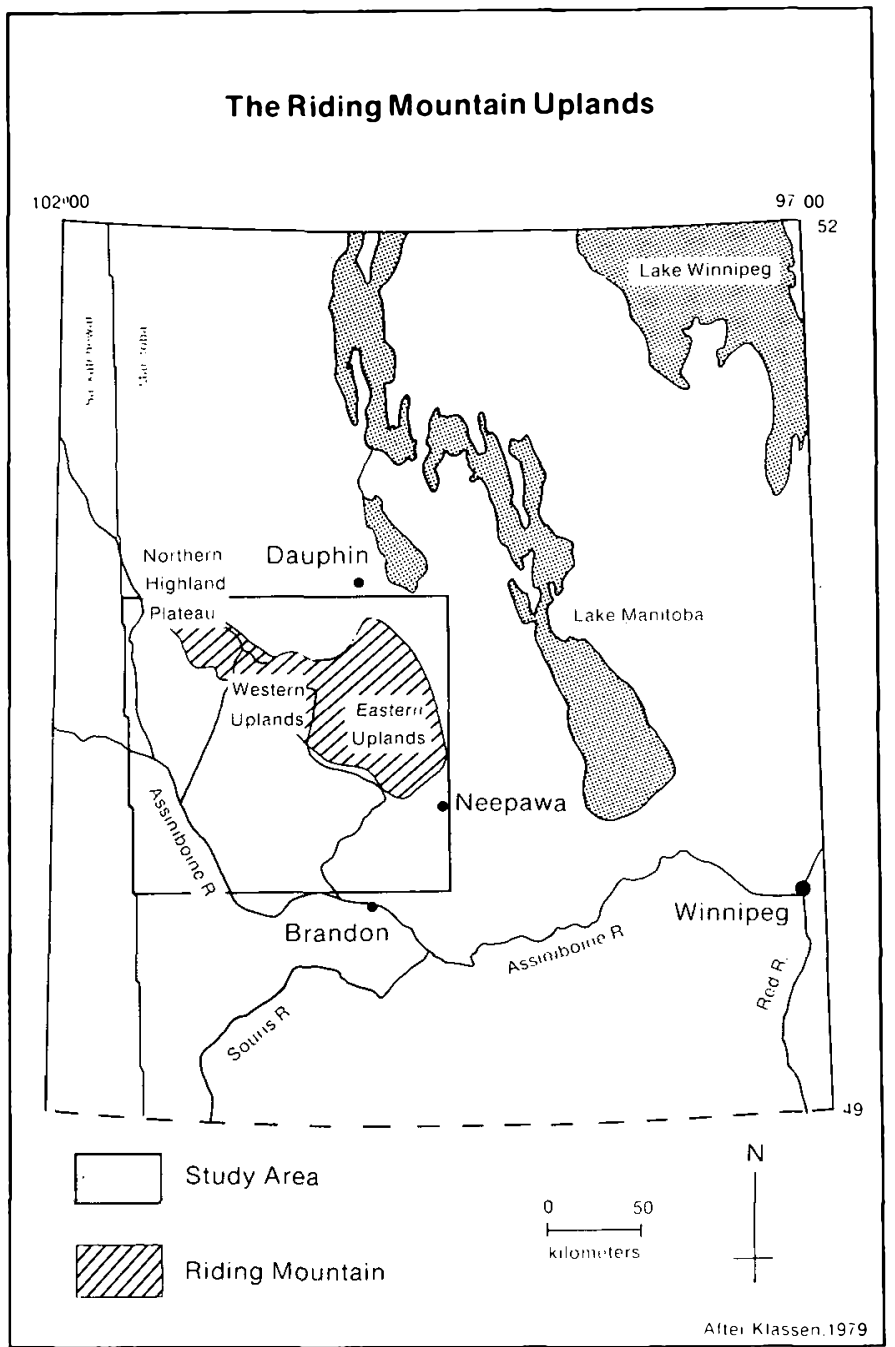

Fig. 1. In the study area, the Riding Mountain Uplands are naturally subdivided into three highland plateaux; the Eastem Uplands, the Western Uplands, and the Northern Highland Plateau.

author has conducted field mapping in the Eastern Uplands particularly along entrenched spillway and meltwater channels. Associated lacustrine and outwash deposits have also been studied. Many of Klassen's sites were revisited as well as prominent exposures marked on the Mihychuk and Groom preliminary map. Some of this research has been presented at the CANQUA and INQUA meetings over the last six years. This paper proposes to reconstruct the late Wisconsinan deglaciation of the Riding Mountain Uplands as it pertains to the development and draining of prominent proglacial and superglacial lakes in the region. It relies heavily on the original mapping and interpretation by R.W. Klassen.

\section{Late Wisconsinan Deglaciation}

\section{The Falconer ice advance}

The last glaciation of the Riding Mountain area (Fig. 1) occurred during the late Wisconsinan (20,000-12,000 B.P.).
Glacial ice covered the entire region and generally flowed towards the southeast across the Assiniboine Plain (Klassen, 1989). During deglaciation, however, retreating ice divided into several topographically controlled sublobes. Parts of the Assiniboine Lobe (Northwestern ice) continued to flow towards the east and southeast. The Red River Lobe (Northeastern ice) pushed into re-entrants in the Manitoba Escarpment occupied by the Valley River Valley and the Assiniboine Valley. The Valley River Sublobe flowed over the northeastern part of the Riding Mountain Uplands towards the southwest, while the Assiniboine Sublobe flowed west and in some areas northwest over the escarpment slope (Klassen, 1966).

\section{Waning of Falconer ice (11,400 B.P.)}

Waning and downmelting of the Falconer ice advance (11,400 B.P.) (Fenton et al., 1983) resulted in the stagnation of glacial ice on the Eastern Uplands of Riding Mountain (Fig. 2). Meltwaters ponded over the stagnant ice, creating four small superglacial lakes near Scandinavia, Hilltop, and Bethany. Three larger superglacial lakes formed near Rackham, Whirlpool Lake and along the western margin of the active Northeastern ice from Lake Ritchie in the north to Muskrat Lake in the south. The largest superglacial lake, near Rackham, has been named glacial Lake Proven (Klassen, 1966). In this paper it is proposed that the ice marginal lake be named glacial Lake Rowland.

At this time, the eastern ridge of the Horod Moraine was built along the northwestern shore of glacial Lake Proven. Stratigraphic sections in the moraine indicate that this feature is an ice marginal ridge (Jurgaitis and Juozapavičius, 1988) characterized by stratified and unstratified sands and gravels, till inclusions and slump features. Along the northern shore of glacial Lake Proven, from Crawford Park to Onanole, outwash was deposited into the rising lake waters. The finer silt settled out in the deeper waters near Rackham. Much of the silt that caps the hummocky topography in this area was deposited in glacial Lake Proven. Roadcut exposures of approximately $8 \mathrm{~m}$ of laminated silt (Klassen, 1979) suggest that glacial Lake Proven existed for a considerable time before a major drainage outlet was established. Towards the south, glacial Lake Hind formed in a re-entrant between the Assiniboine Lobe and the Red River Lobe (Assiniboine Sublobe).

\section{Sublobe development}

As the Assiniboine Sublobe separated from the Assiniboine Lobe, downwasting resulted in the stagnation of glacial ice on the Western Uplands of the Riding Mountain Uplands (Fig. 3). The main complex of the Horod Moraine accumulated in a re-entrant between the Valley River Sublobe and the stagnant ice to the south. Towards the west, meltwaters flowed along the northern edge of the stagnant ice, ponding in two small superglacial lakes located between Seech and the eastern ridge of the Horod Moraine. An 


\section{Stage I Waning Falconer Ice 11,400 B.P.}

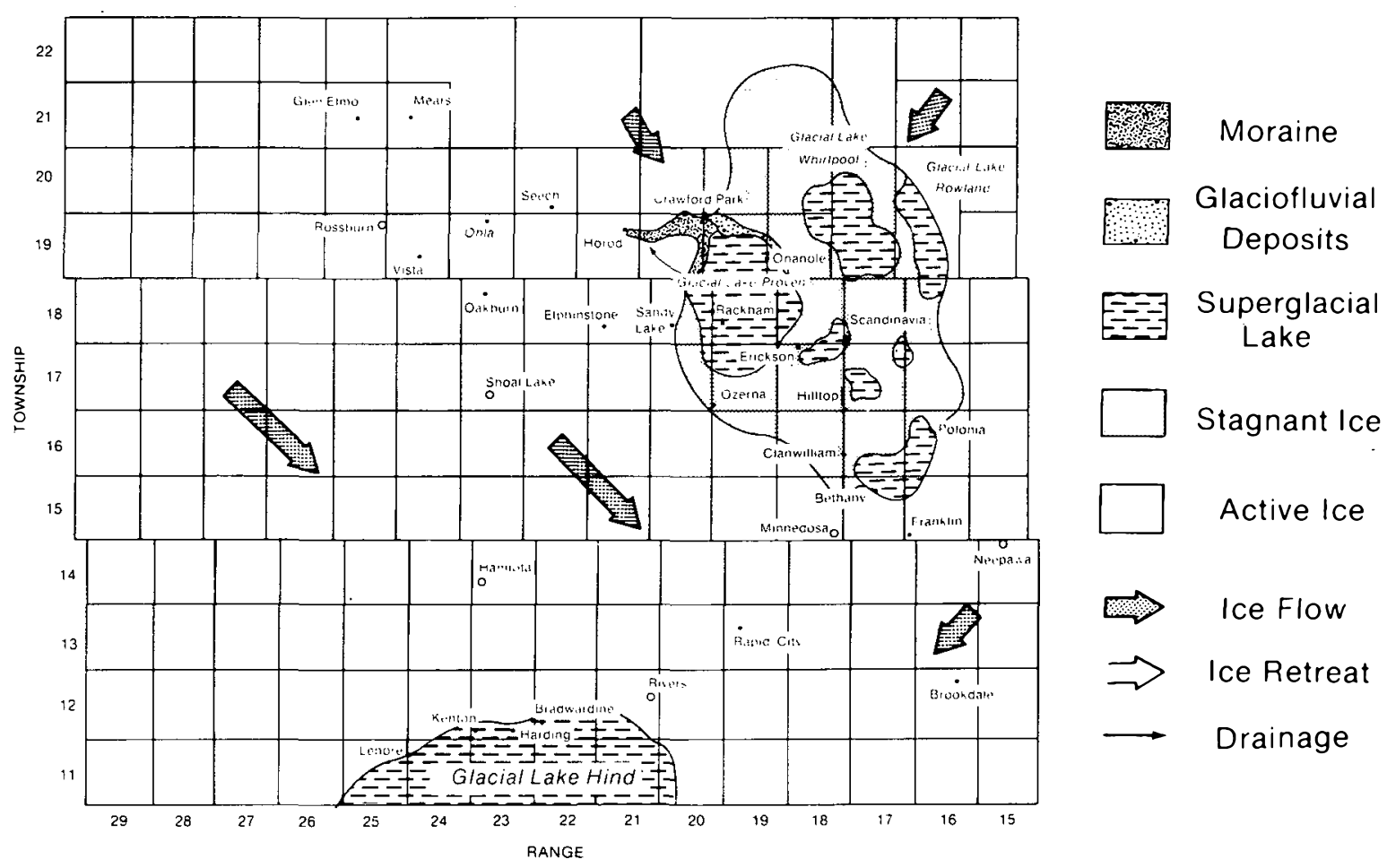

Fig. 2. Waning and downmelting of Falconer ice resulted in the stagnation of glacial ice on the Eastern Uplands of Riding Mountain.

\section{Stage II Sublobe Development}

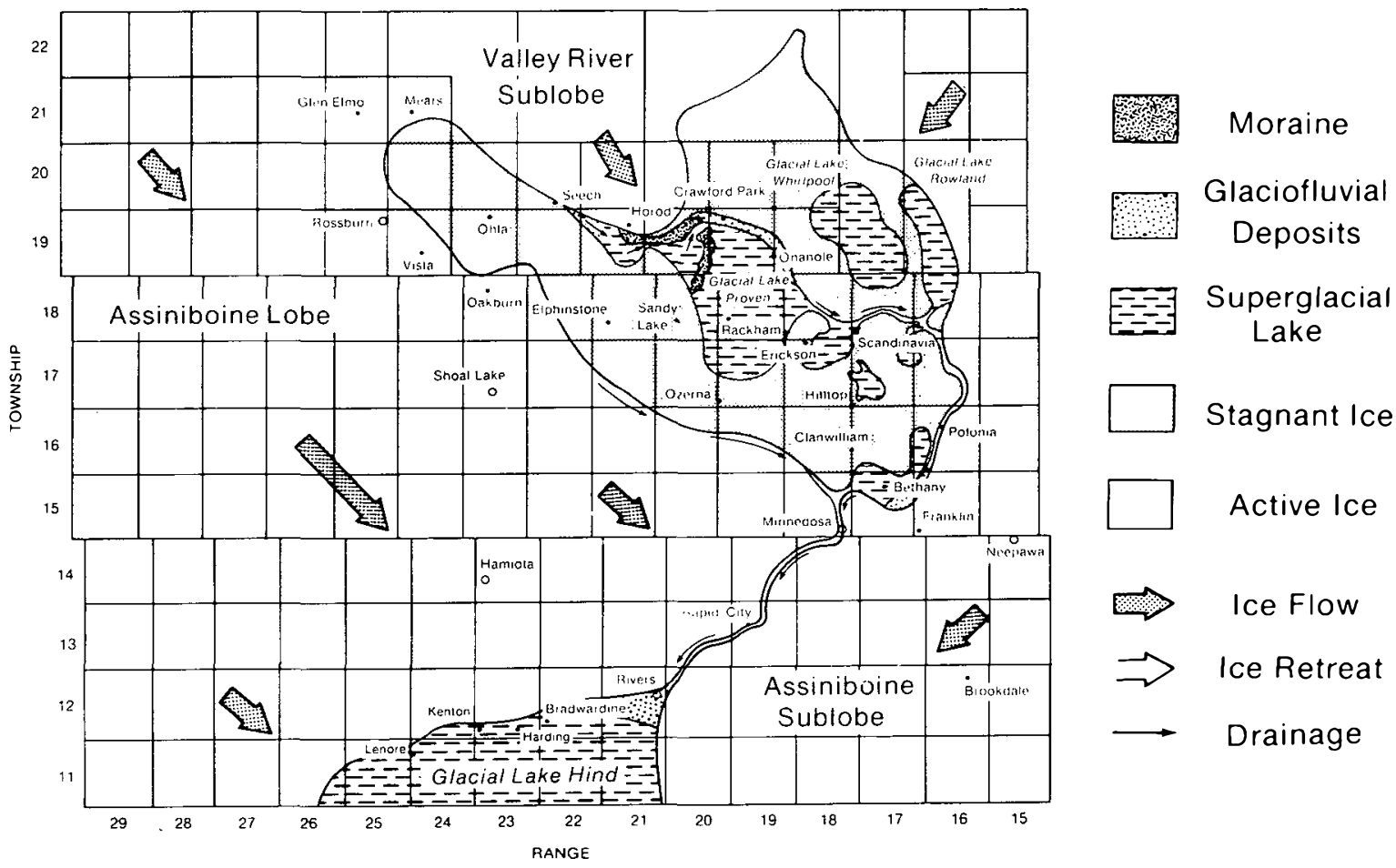

Fig. 3. As the Assiniboine Sublobe separated from the Assiniboine Lobe, downwasting resulted in the stagnation of glacial ice on the Western Uplands. 
outwash fan was deposited by these meltwaters and as lake levels rose, the Horod Moraine was breached near Crawford Park.

An ice marginal meltwater channel heading in glacial Lake Rowland drained southward through the McFadden Valley and the Polonia Trench into an ice marginal glacial lake near Bethany. This lake also drained southward, along an ice marginal meltwater channel which separated the two active ice lobes, into an expanding glacial Lake Hind. Klassen (1966) suggests that glacial Lake Proven may have spilled across the stagnant ice towards the east. A drainage way was established by way of the Upper Rolling River Valley to the McFadden Valley and from there to glacial Lake Hind. A third ice marginal meltwater channel formed between the northern flank of the Assiniboine Lobe and the stagnant ice on the uplands. Coarse sediment transported by this meltwater stream was eventually deposited as a delta building into the northern embayment of glacial Lake Hind.

\section{The Valley River advance}

The glacier was now stagnant over most of the Riding Mountain Uplands and the Assiniboine Sublobe was in the process of retreating to the Brookdale position (Fig. 4).

Near Mears a kame moraine accumulated in a re-entrant between the re-advancing Valley River Sublobe to the north and the western Assiniboine Lobe. Meltwaters from the Valley River Sublobe flowed in a network of ice-walled drainage channels across the narrow belt of stagnant ice between the two lobes. Drainage within the belt was poorly integrated and only the ice marginal meltwater channel developed as a continuous valley (Klassen, 1966). This ice marginal channel, recognized today as Heron Creek, continued to build a subaqueous outwash fan into the expanding proglacial Lake Horod near Seech. This superglacial lake drained south and then east, around the northern complex of the Horod Moraine into glacial Lake Proven.

The large superglacial lake near Whirlpool Lake spilled over the stagnant ice to the southwest. The discharge waters quickly eroded a channel through the stagnant ice and into the underlying till. The scoured material was deposited in a braidplain outwash fan as the flow entered a smaller superglacial lake near Scandinavia. Paleocurrent indicators (dune foresets) exposed in the Upper Rolling River Valley, suggest that both the small superglacial lake and glacial Lake Whirlpool drained westward into glacial Lake Proven. If this were the case, it appears that the draining of glacial Lake Whirlpool reversed the stream flow direction along the Upper Rolling River Spillway. Consequently, glacial Lake Proven could not drain eastward into the McFadden Valley-Polonia Trench system. As lake levels rose, glacial Lake Proven spilled over the stagnant ice to the south. The overflow discharge rapidly cut a straight channel through the stagnant ice and into the underlying till. Lake waters could now drain southward down the freshly cut Lower Rolling River Spillway into the ice marginal meltwater channel which had

\section{Stage III The Valley River Advance}

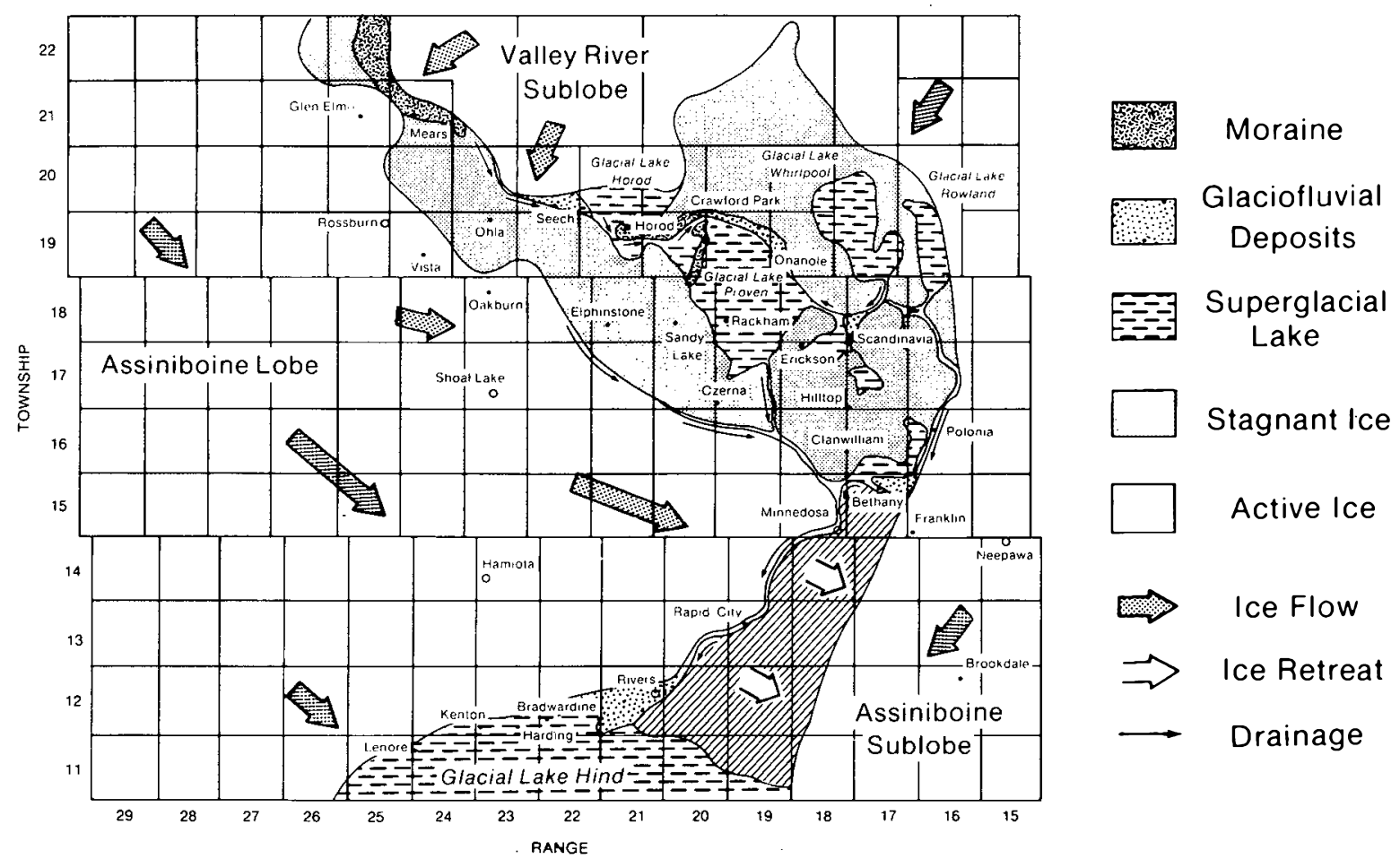

Fig. 4. Near Mears a kame moraine accumulated in a re-entrant between the re-advancing Valley River Sublobe to the north and the western Assiniboine Lobe. 
formed along the northern flank of the Assiniboine Lobe. Later this entrenched meltwater channel would become part of the Little Saskatchewan River Valley.

Proglacial Lake Rowland continued to drain along the McFadden Valley and Polonia Trench into glacial Lake Bethany. Sediment transported through this system was deposited as a subaqueous outwash fan built into the southeastern end of the lake. A large percentage of the fan sediments is local shale gravels. This and other sedimentological data indicate that the fan sediments were derived from material scoured from the deeply incised McFadden Valley and the Polonia Trench. Glacial Lake Bethany drained westward into the Little Saskatchewan meltwater channel and from there southward into glacial Lake Hind.

\section{The retreat of the Assiniboine and Valley River sublobes}

As the Assiniboine Sublobe came to a stillstand near Brookdale, the Valley River Sublobe retreated to a position along the northern boundary of Riding Mountain National Park (Fig. 5). On the uplands the stagnant ice continued to thin by downmelting.

In the Western Uplands meltwaters generally drained by a network of ice-walled channels towards the margins of the stagnant ice. However, one established channel, Heron Creek, drained eastward into an expanding proglacial Lake Horod. An ice marginal meltwater stream formed along the south- western edge of the Valley River Sublobe. This sediment laden river also flowed east, over a broad sandur plain, eventually discharging into glacial Lake Horod. A greater volume of water was now entering the lake than was being discharged through the outlet. The southern outlet channel, located near Horod, was bounded on the east by the western end of the Horod Moraine and on the west by debris-laden stagnant ice. For a short period lake levels rose while the outlet channel experienced regime adjustment. During this time, it is estimated that approximately $1 \mathrm{~km}$ of the western end of the Horod Moraine was eroded, effectively widening the outlet channel. This channel regime adjustment permitted a greater volume of lake discharge to pass through the outlet, re-establishing the lake's mass equilibrium. Downstream regime adjustments naturally followed.

The complex routing of glacial Lake Horod discharge through two small superglacial lakes and the Crawford Park breach into glacial Lake Proven resulted in relatively large run-through times. Consequently, for a short period, lake levels rose. The overflow discharge spilled southward across the downwasting stagnant ice. The flow quickly cut a channel through the thin stagnant ice and into the till substratum. This newly formed drainage channel joined the evolving Little Saskatchewan ice marginal meltwater channel near Elphinstone. From there, lake waters mixed with meltwaters and flowed southeast towards Minnedosa, joining the outflow from glacial Lake Proven (the Lower Rolling River Spillway) and glacial Lake Bethany. Near Minnedosa the spillway

\section{Stage IV Retreat of the Assiniboine Sublobe}

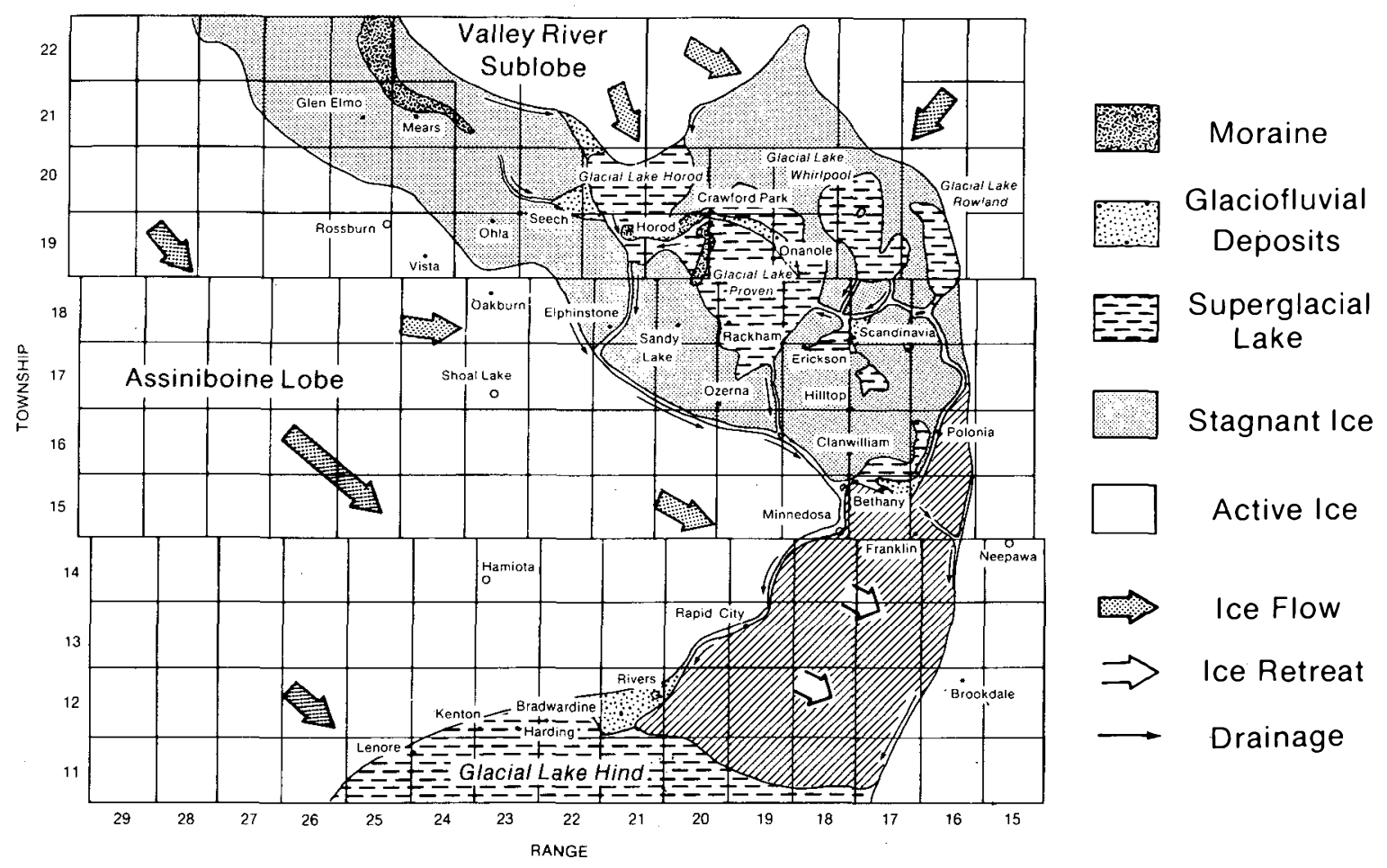

Fig. 5. As the Assiniboine Sublobe came to a stillstand near Brookdale, the Valley River Sublobe retreated to a position along the northern boundary of the uplands. 
system made an abrupt turn towards the southwest as it joined a former ice marginal meltwater channel (Fig. 3).

Forty kilometres downstream the spillway system discharged into glacial Lake Hind. Much of the coarse material transported along this spillway-meltwater channel system was eventually deposited in a large delta built into the lake near Rivers.

\section{Pre-Marchand advance (11,200 B.P.)}

Once the individual components of the Little Saskatchewan spillway-meltwater channel system had entrenched into the substratum, the superglacial lakes drained (Fig. 6). Of the large proglacial and superglacial lakes, only glacial Lake Rowland persisted at the close of the Superglacial Lake Phase in the deglaciation of the Riding Mountain Uplands.

\section{Summary}

During the waning of the Falconer ice advance (post 11,400 B.P.) (Fenton et al., 1983) a large area of glacial ice stagnated on the Riding Mountain Uplands. Meltwaters ponded over the stagnant ice, creating large superglacial lakes near Horod, Rackham, Whirlpool Lake and along the eastern margin of the stagnant ice. Subsequent downwasting generated a drainage network consisting of several meltwater channels and spillways linking the superglacial pondings to an ice marginal meltwater stream which drained into glacial
Lake Hind. Many of these glacial rivers eroded their ice beds and incised into the substratum. Glaciofluvial sediments were deposited as sandurs, eskers and kames. Subaqueous fans were deposited in the superglacial lakes and a major delta was built into the north end of glacial Lake Hind. Downwasting continued and at the time of the Marchand advance (11,200 B.P.) (Fenton et al., 1983) the superglacial lakes had drained and much of the present day entrenched drainage system had formed in the stagnant ice moraine complex on the Riding Mountain Uplands.

Groom, H. 1980. The surficial geology of the South Riding Mountain Planning District. Manitoba Mineral Resources Division, Report of Field Activities, 1980, pp. 82-83.

Fenton, M.M., Moran, S.R., Teller, J.T., and Clayton, L. 1983. Quaternary stratigraphy and history in the southern part of the Lake Agassiz basin. In Glacial Lake Agassiz. Edited by J.T. Teller and L. Clayton. Geological Association of Canada, Special Paper 26, pp. 49-74.

Jurgaitis, A. and Juozapa vičrıus, G. 1988. Genetic classification of glaciofluvial deposits and criteria for their recognition. In Genetic Classification of Glacigenic Deposits. Edited by R.P. Goldthwait and C.L. Matsch. A.A. Balkema, Rotterdam, pp. 227-242.

KLASSEN, R.W. 1966. The surficial geology of the Riding Mountain area, Manitoba-Saskatchewan. Ph.D. thesis, University of Saskatchewan, Saskatoon, Saskatchewan, 162 p.

1979. Pleistocene geology and geomorphology of the Riding Mountain and Duck Mountain areas, Manitoba-Sas-

\section{Stage V Pre-Marchand 11,200 B.P.}

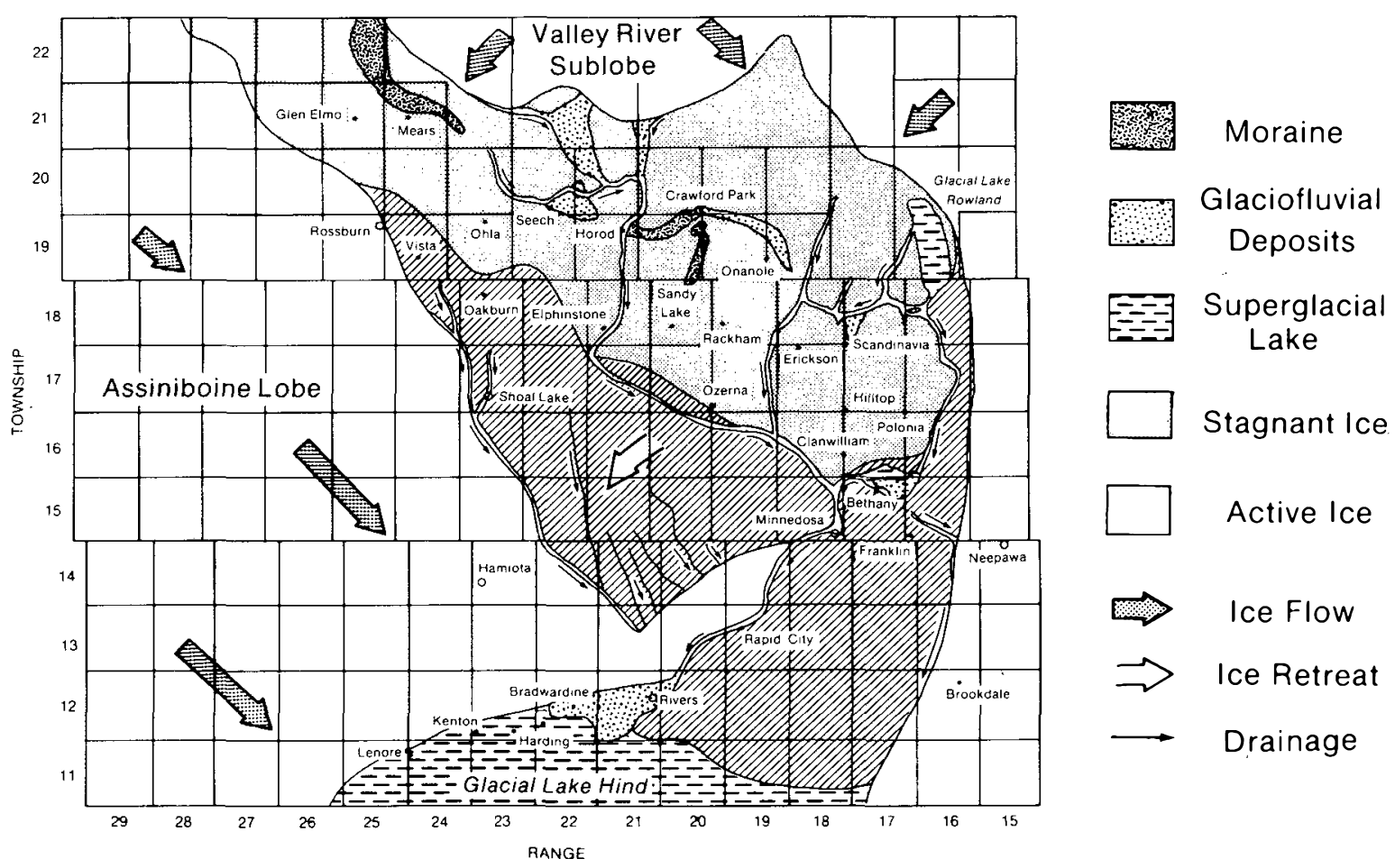

Fig. 6. Once the individual components of the Little Saskatchewan spillway-meltwater channel system had entrenched into the substratum, the superglacial lakes drained. 
katchewan. Geological Survey of Canada, Memoir 396, 52 p. 1989. Quaternary geology of the southern Canadian Interior Plains. In Quaternary Geology of Canada and Greenland. Edited by R.J. Fulton. Geological Survey of Canada, Ottawa, pp. 143-176.
MinychuK, M. and Groom, H. 1979. Quaternary geology and aggregate resources of the Neepawa area. Manitoba Mineral Resources Division, Report of Field Activities 1979. Preliminary Maps 1979 PN-1 and 2. 